\title{
Risk of perinatal transmission of hepatitis B virus in Jordan
}

\author{
Naji Batayneh and Salwa Bdour
}

Department of Biological Sciences, Faculty of Science, University of Jordan, Amman, Jordan

\begin{abstract}
Objectives: To determine the risk of perinatal transmission of hepatitis B virus (HBV) in Jordan.
Methods: Plasma samples from 1000 pregnant Jordanian women were screened by ELISA for HBV markers (HBsAg, $\mathrm{HBeAg}$, anti-HBe, anti-HBc and anti-HBs).

Results: $\mathrm{HBsAg}$ and $\mathrm{HBeAg}$ were detected in $4.3 \%$ and $0.1 \%$ of the pregnant women, respectively. The overall prevalence of antibodies was $6 \%, 11.1 \%$ and $7.5 \%$ for anti-HBe, anti-HBc and anti-HBs, respectively. Women were assigned to four groups according to the serological patterns of HBV markers: susceptible (85.9\%), with acute infection (2.9\%), with chronic infection (1.4\%) and previously infected (9.8\%). Most women were at the third trimester of pregnancy, therefore women with acute and chronic hepatitis at this gestational age were at risk of transmitting HBV infection to their newborns. Women who belonged to the low socio-economic class were at higher risk of HBV infection.

Conclusions: Based on the results, we recommend screening women for HBV during pregnancy in order to identify HBV carriers. All newborns born to carriers should be vaccinated immediately after birth, both passively and actively. Also vaccination of HBV seronegative pregnant women is recommended.
\end{abstract}

Key words: Hepatitis B markers; Pregnancy; Maternal Transmission of HBV; Jordan

Perinatal transmission of hepatitis B virus (HBV) is an important route of infection. It occurs mainly in infants due to exposure to infected blood and genital secretions during delivery ${ }^{1,2}$ and to in utero passage of $\mathrm{HBV} \mathrm{DNA}^{3}$. In the absence of immunoprophylaxis, perinatal transmission occurs in 10-20\% of women who are seropositive for hepatitis B surface antigen (HBsAg) and up to $90 \%$ in women who are seropositive for both HBsAg and hepatitis $B$ e antigen $(\mathrm{HBeAg})^{4,5}$. Newborns to HBsAg-positive mothers who do not become infected at birth remain at high risk of infection until the age of 5-6 years ${ }^{4}$. However, newborns of $\mathrm{HBeAg}$ positive women are carriers and at risk of long-term complications of hepatitis B infection including cirrhosis and hepatocellular carcinoma $^{6,7}$. They may not eliminate the virus despite passive-active immunization ${ }^{8}$.
To prevent HBV infection, a universal strategy has been adopted by many countries ${ }^{9}$. The strategy is based on screening pregnant women for $\mathrm{HBV}$ markers and providing passive and active immunization to newborns of potentially infectious mothers.

In Jordan, hepatitis B vaccine has been integrated into the current childhood immunization program since 1995. But screening of pregnant or childbearing women for HBV markers is not a routine test. Therefore, the need to know the prevalence of $\mathrm{HBV}$ in pregnancy and the risk of perinatal transmission of HBV is vital in the planning of preventive measures. For this reason, the present study has been conducted to: (1) provide information on the prevalence of HBV markers among pregnant women in Jordan; (2) examine the relationship between HBV seropositivity and

This research was supported by the Deanship of Scientific Research of the University of Jordan.

Correspondence to: Naji Batayneh, Department of Biological Sciences, Faculty of Science, University of Jordan, Amman, Jordan.

Email: bsalwa@sci.ju.edu.jo 
risk factors; and (3) evaluate the possibility of maternal transmission in view of seroprevalence of $\mathrm{HBV}$ markers in pregnant women.

\section{SUBJECTS AND METHODS}

\section{Subjects}

One thousand pregnant Jordanian women aged 15-44 years, attending the antenatal clinic in Amman and Al-Salt, were randomly studied. The implications of chronic HBV infection and the risks of transmission of the virus to the infant were explained to the participating women, and their consent to take part in the study was obtained. Each woman completed a questionnaire that included: age, history of hepatitis, blood transfusion, hemodialysis, surgery and dental procedure and socioeconomic status, which was determined based on family size and annual family income.

\section{Serology}

Five milliliters of blood was taken from each woman. The plasma was separated, aliquoted and stored at $-20^{\circ} \mathrm{C}$ until assayed. Plasma samples were tested for antibody against hepatitis $\mathrm{B}$ core antigen (anti-HBc), HBsAg and its antibody (anti-HBs) and $\mathrm{HBeAg}$ and its antibody (anti-HBe) by commercially available ELISA kits (DiaSorin, Italy).

\section{Biochemical tests}

The levels of alanine transaminase (ALT) and aspartate aminotransferase (AST) in each plasma sample were measured by spectrophotometer using commercially available ALT and AST testing kits (Menagent, Italy) according to the manufacturer's instructions.

\section{Statistical analysis}

The data were analyzed statistically using the Chi-square test. $P$ values of less than 0.05 were considered significant.

\section{RESULTS}

\section{Prevalence of HBV serological markers}

As shown in Table 1, HBsAg was found in $4.3 \%$ of plasma samples, indicating acute or chronic infection with HBV. Only one woman was found positive for $\mathrm{HBeAg}$, indicating also acute or chronic infection. The overall prevalence of antibodies was $6 \%, 11.1 \%$ and $7.5 \%$ for anti-HBe, anti-HBc and anti-HBs, respectively. Presence of these antibodies indicates chronic infection or recovery from acute infection. There was no significant difference among age groups with respect to the prevalence of HBV antigens and antibodies.

\section{Liver function tests}

All women with the serological markers shown in Table 1 had transaminases within the normal range, indicating the absence of liver damage.

\section{Hepatitis B status}

The women were divided into four groups (I-IV) according to the serological patterns of $\mathrm{HBV}$ markers (Table 2). Eight hundred and fifty-nine

Table I Seroprevalence of HBV markers in pregnant Jordanian women by age

\begin{tabular}{|c|c|c|c|c|c|c|c|c|c|c|}
\hline \multirow[b]{3}{*}{ Age } & \multicolumn{10}{|c|}{ Number of positive women } \\
\hline & \multicolumn{2}{|c|}{$H B s A g$} & \multicolumn{2}{|c|}{$H B e A g$} & \multicolumn{2}{|c|}{ anti-HBe } & \multicolumn{2}{|c|}{ anti-HBc } & \multicolumn{2}{|c|}{ anti-HBs } \\
\hline & $\mathrm{n}$ & (\%) & $\mathrm{n}$ & (\%) & $\mathrm{n}$ & (\%) & $n$ & (\%) & $\mathrm{n}$ & (\%) \\
\hline $15-24$ & 16 & 1.6 & I & 0.1 & 15 & 1.5 & 25 & 2.5 & 15 & 1.5 \\
\hline $25-34$ & 15 & 1.5 & 0 & 0 & 30 & 3 & 56 & 5.6 & 37 & 3.7 \\
\hline $34-44$ & 12 & 1.2 & 0 & 0 & 15 & 1.5 & 30 & 3 & 23 & 2.3 \\
\hline Total & 43 & 4.3 & I & 0.1 & 60 & 6 & $\mathrm{III}$ & II.I & 75 & 7.5 \\
\hline
\end{tabular}


women were susceptible to HBV infection due to the absence of all serological HBV markers (group I). A total of 141 women showed HBV serological markers; forty-three of them were HBsAg-positive and 98 were $\mathrm{HBsAg-negative.} \mathrm{Of}$ the $43 \mathrm{HBs} A$ g-positive women, 28 were at the incubation period (group IIa), one was at the acute phase of infection (group IIb) and 14 had chronic infection (group IIIa,b). Of the $98 \mathrm{HBsAg-}$ negative women, 41 were at recovery phase or convalescence with typical HBV antibody markers (group IVa), while 57 were at this phase with loss of one or two of the antibodies (group $\mathrm{IVb}-\mathrm{d}$ ).

\section{Prevalence of HBV infection according to socio-economic status}

Data presented in Table 3 clearly demonstrate that most women (685) have a low socio-economic status, while 312 and 3 women have mid and high status, respectively. HBV infection is correlated inversely with socio-economic status. All women of higher status were susceptible to HBV and none had hepatitis at the time of or prior to the study. In contrast, 276 and 580 women of mid and low status, respectively, were susceptible (group I) and the rest had hepatitis at the time of the study (groups II and III) or had recovered from hepatitis (group IV).

Table 2 Hepatitis B status of Jordanian pregnant women

\begin{tabular}{|c|c|c|c|c|c|c|c|c|c|}
\hline \multirow[b]{2}{*}{ Group } & & \multirow[b]{2}{*}{ Maternal status } & \multicolumn{5}{|c|}{ HBV serological markers } & \multicolumn{2}{|c|}{ Total } \\
\hline & & & $H B s A g$ & $H B e A g$ & anti-HBe & anti-HBc & anti-HBs & $n$ & (\%) \\
\hline I & & Susceptible & - & - & - & - & - & 859 & 85.9 \\
\hline \multirow[t]{2}{*}{ II } & $\mathrm{a}$ & Acute infection (incubation period) & + & - & - & - & - & 28 & 2.8 \\
\hline & $\mathrm{b}$ & Acute infection (acute phase) & + & + & - & + & - & I & 0.1 \\
\hline \multirow[t]{2}{*}{ III } & $\mathrm{a}$ & Chronic infection & + & - & + & - & - & 2 & 0.2 \\
\hline & $\mathrm{b}$ & Chronic infection & + & - & + & + & - & 12 & 1.2 \\
\hline \multirow[t]{4}{*}{ IV } & $\mathrm{a}$ & Recovery or convalescence & - & - & + & + & + & $4 I$ & 4. I \\
\hline & $b$ & Recovery with loss of anti-HBs & - & - & + & + & - & 5 & 0.5 \\
\hline & c & Recovery with loss of anti-HBe & - & - & - & + & + & 32 & 3.2 \\
\hline & $d$ & $\begin{array}{l}\text { Recovery with loss of anti-HBs and } \\
\text { anti-HBe }\end{array}$ & - & - & - & + & - & 20 & 2 \\
\hline
\end{tabular}

+ , positive result; - , negative result

Table 3 Prevalence of HBV infection in pregnant Jordanian women, stratified by socio-economic status

\begin{tabular}{|c|c|c|c|c|c|c|c|c|c|c|}
\hline \multirow[b]{2}{*}{ Characteristics } & \multicolumn{2}{|c|}{$\begin{array}{l}\text { Group I } \\
(n=859)\end{array}$} & \multicolumn{2}{|c|}{$\begin{array}{l}\text { Group II } \\
(n=29)\end{array}$} & \multicolumn{2}{|c|}{$\begin{array}{l}\text { Group III } \\
(n=14)\end{array}$} & \multicolumn{2}{|c|}{$\begin{array}{l}\text { Group IV } \\
(n=98)\end{array}$} & \multicolumn{2}{|c|}{$\begin{array}{c}\text { Total } \\
(n=1000)\end{array}$} \\
\hline & $n$ & (\%) & $n$ & (\%) & $n$ & (\%) & $n$ & (\%) & $n$ & (\%) \\
\hline \multicolumn{11}{|c|}{ Economic status } \\
\hline High & 3 & 0.3 & 0 & 0 & 0 & 0 & 0 & 0 & 3 & 0.3 \\
\hline Mid & 276 & 32.2 & 7 & 24.1 & 2 & 14.3 & 27 & 27.5 & 312 & 31.2 \\
\hline Low & 580 & 67.5 & 22 & 75.9 & 12 & 85.7 & 71 & 72.5 & 685 & 68.5 \\
\hline Employed & 60 & 7 & 5 & 0.5 & 0 & 0 & 5 & 5.1 & 70 & 7 \\
\hline Unemployed & 799 & 93 & 24 & 2.4 & 14 & 1.4 & 93 & 94.9 & 930 & 93 \\
\hline
\end{tabular}


$\mathrm{HBV}$ infection is significantly higher in women of lower socio-economic status than in those of mid status $(p<0.01)$. Most HBsAg-positive women were of low status. Twenty-two HBsAgpositive women with acute hepatitis (group II) were of low socio-economic status compared with seven of mid status. Twelve HBsAg-positive women with chronic hepatitis (group III) were of low status while two were of mid status. Similarly, 71 women who had hepatitis prior to the study (group IV) were of low status while 27 were of mid status.

The majority of women (930) were unemployed; there was a higher prevalence of $\mathrm{HBV}$ infection among unemployed than employed women (Table 3). Sixty employed and 799 unemployed women, respectively, were susceptible to HBV infection (group I). Most HBsAgpositive women (24) with acute hepatitis (group II) and all HBsAg-positive women with chronic hepatitis (group III) were unemployed.

\section{Prevalence of HBV infection in relation to risk factors}

Data presented in Table 4 is based on the answers in the questionnaire. Only two women reported a history of hepatitis, 117 had a blood transfusion, five had hemodialysis, 776 had a dental procedure and 417 had undergone surgery. There were no significant differences between groups I-IV with respect to these risk factors $(p=0.5-0.9)$.

\section{DISCUSSION}

Maternal screening and treatment of newborns by passive and active immunization can control perinatal transmission of HBV. Screening of pregnant Jordanian women revealed that $4.3 \%$ were HBsAg positive with acute or chronic hepatitis. There was no significant difference in the prevalence of HBsAg in different age groups. Similar results were reported by other investigators ${ }^{10}$. In other parts of the world, the prevalence of $\mathrm{HBsAg}$ in pregnant women has been reported as $0.1-39.7 \%{ }^{10-13}$.

One out of the 1000 pregnant women was found positive for $\mathrm{HBeAg}$. Higher prevalence has been reported in pregnant women: $4.6 \%$ in South Africa ${ }^{14}, 6.2 \%$ in Turkey ${ }^{13}$ and $43 \%$ in Taiwan ${ }^{10}$.

Presence of $\mathrm{HBsAg}$ or both $\mathrm{HBsAg}$ and $\mathrm{HBeAg}$ in pregnant Jordanian women indicates high risk of maternal-fetal transmission. Their newborns should receive hepatitis $\mathrm{B}$ immunoglobulin (HBIG) immediately after birth and vaccination within 12 hours of birth.

Screening of Jordanian women for HBV antibodies revealed that $6 \%, 11.1 \%$ and $7.5 \%$ were positive for anti-HBe, anti-HBc and anti-HBs, respectively. Presence of anti-HBe indicates a risk of perinatal transmission in those with chronic infection. Anti-HBs was found in most anti-HBc mothers who had hepatitis indicating that those women are immunized and there is no risk of maternal transmission. Anti-HBc was detected in most women with chronic infection and in all women who had hepatitis. Lower prevalence of

Table 4 Prevalence of HBV infection in pregnant Jordanian women in relation to risk factors

\begin{tabular}{|c|c|c|c|c|c|c|c|c|c|c|}
\hline \multirow[b]{2}{*}{ Characteristics } & \multicolumn{2}{|c|}{$\begin{array}{c}\text { Group } \\
(n=859)\end{array}$} & \multicolumn{2}{|c|}{$\begin{array}{l}\text { Group II } \\
(n=29)\end{array}$} & \multicolumn{2}{|c|}{$\begin{array}{l}\text { Group II } \\
(n=14)\end{array}$} & \multicolumn{2}{|c|}{$\begin{array}{l}\text { Group IV } \\
(n=98)\end{array}$} & \multicolumn{2}{|c|}{$\begin{array}{c}\text { Total } \\
(n=1000)\end{array}$} \\
\hline & $n$ & (\%) & $n$ & (\%) & $n$ & (\%) & $n$ & (\%) & $n$ & (\%) \\
\hline History of hepatitis & 0 & 0 & 0 & 0 & I & 7.1 & 2 & 2 & 2 & 0.2 \\
\hline History of blood transfusion & 99 & 11.5 & 3 & 10.3 & 3 & 21.4 & 12 & 12.3 & 117 & 11.7 \\
\hline History of hemodialysis & 4 & 0.5 & 0 & 0 & 0 & 0 & 1 & I & 5 & 0.5 \\
\hline Dental procedure & 658 & 76.6 & 22 & 75.9 & 13 & 92.9 & 83 & 84.7 & 776 & 77.6 \\
\hline Surgery & 350 & 40.7 & 10 & 34.5 & 8 & 57.1 & 49 & 50 & 417 & 41.7 \\
\hline
\end{tabular}


anti-HBc was reported in Swiss (3.3\%), Spanish $(3.7 \%)$ and Portuguese (5.4\%) women ${ }^{12}$. Higher prevalence was reported in ex-Yugoslavian (18.6\%), Turkish (29.9\%) and African (39.7\%) women $^{12}$. Of special interest is the group of 20 anti-HBc positive women with 'isolated anti-HBc'. They could either have recovered from acute $\mathrm{HBV}$ infection and cleared HBsAg but not yet developed anti-HBs, or infected for a long time and lost both anti-HBe and anti-HBs. In the former case, newborns - especially for mothers in the third trimester - could be at risk of in utero infection which might occur some time before delivery, as reported in pregnant Swiss women ${ }^{12}$. To eliminate the risk of perinatal transmission in Jordan, we also recommend active and passive immunization of newborns of this group of women.

In the present study, $85.9 \%$ of women are susceptible to HBV infection and need vaccination and follow-up during pregnancy. Their infants require only vaccination ${ }^{15}$ according to the immunization program in Jordan.

Most women, including those who have acute and chronic infection, are of low socioeconomic status. Intrafamilial transmission might occur due to sharing of facilities and overcrowding (median number of family members before marriage $=10$; median number of children $=4$ ). There was no statistical difference among the groups of women according to the risk factors (Table 4). We concluded that blood transfusion, hemodialysis, surgery and dental procedure are not major routes of HBV infection in the population studied.

In conclusion, we reinforce the potential value of the vaccination program targeted at Jordanian children in early life along with passive immunization of newborns of $\mathrm{HBsAg}$-positive and $\mathrm{HBeAg}$-positive mothers. Seroprevalence surveys of HBV infection in children must be carried out to determine the effectiveness of the HBV vaccination program in Jordan. We also recommend HBV screening during pregnancy and possibly vaccination of pregnant women.

\section{ACKNOWLEDGMENTS}

We gratefully thank the Deanship of Scientific Research of the University of Jordan for financial support. We are grateful to the Minister of Health who agreed to collection of blood samples from pregnant women. We gratefully thank Miss Dua' Salah Nazzal for her technical assistance and typing of the manuscript.

\section{REFERENCES}

1. Pujol FH, Rodriguez I, Martinez N, et al. Viral hepatitis serological markers among pregnant women in Caracas, Venezuela: implication for perinatal transmission of hepatitis B and C. GEN 1994;48:25-8

2. Duff P. Hepatitis in pregnancy. Semin Perinatol 1998;22:277-83

3. Lazizi Y, BadurS, Perk Y, et al. Selective unresponsiveness to $\mathrm{HBs} A \mathrm{~g}$ vaccine in newborns related with an in utero passage of hepatitis B virus DNA. Vaccine 1997;15:1095-100

4. Beasly RP, Hwang LY. Postnatal infectivity of hepatitis B surface antigen-carrier mothers. I Infect Dis 1983;147:185-90

5. Bahn A, Hilbert K, Martin U, et al. Selection of a precore mutant after vertical transmission of different hepatitis B virus variants is correlated with fulminant hepatitis in infants. J Med Virol 1995;47: 336-41
6. Beasly RP. Hepatitis B virus: the major etiology of hepatocellular carcinoma. Cancer 1988;61:1942-56

7. Poovorawan Y, Sanpavat S, Pongpunlert W, et al. Protective efficacy of a recombinant DNA hepatitis $\mathrm{B}$ vaccine in neonates of $\mathrm{HbeAg-positive} \mathrm{mothers.}$ J Am Med Assoc 1989;261:3278-81

8. Ngui SL, Andrews NJ, Underhill GS, et al. Failed postnatal immunoprophylaxis for hepatitis $\mathrm{B}$ : characteristics of maternal hepatitis $\mathrm{B}$ virus as risk factor. Clin Infect Dis 1998;27:100-6

9. Andre FE, Zuckerman AJ. Review: Protective efficacy of hepatitis B vaccines in neonates. $\mathrm{J} \mathrm{Med}$ Virol 1994;44:144-51

10. Lin HH, Hsu HY, Lee TY, et al. Age-specific prevalence of hepatitis B surface and e antigenemia in pregnant women in Taiwan. Asia Oceania $J$ Obstet Gyaecol 1994;20:141-5

11. Balistreri WF. Viral hepatitis. Pediatr Clin North Am 1988;35:375-407 
12. Bart PA, Jacquier P, Zuber PLF, et al. 1996. Seroprevalence of HBV (anti-HBc, HbsAg and antiHBs) and HDV infections among 9006 women at delivery. Liver 1996;16:110-16

13. Kuru U, Turan O, Kuru N, et al. Prevalence of hepatitis $\mathrm{B}$ virus in pregnant Turkish women and their families. EurJ Clin Microbiol Infect Dis 1996;15: $248-51$

RECEIVED 11/12/01; ACCEPTED 03/20/02
14. Guidozzi F, Schoub B, Johnson S, Song E. Should pregnant urban South African women be screened for hepatitis B? S Afr Med J 1993;83:103-5

15. Centers for Disease Control. Hepatitis B virus: A comprehensive strategy for eliminating transmission in the United States through universal vaccination: recommendations of the Immunization Practices Advisory Committee (ACIP). MMWR Morb Mortal Wkly Rep 1991;40:1-25 


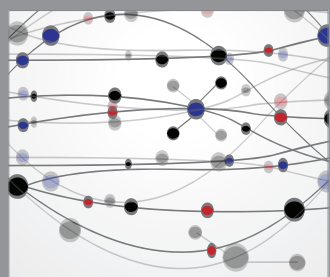

The Scientific World Journal
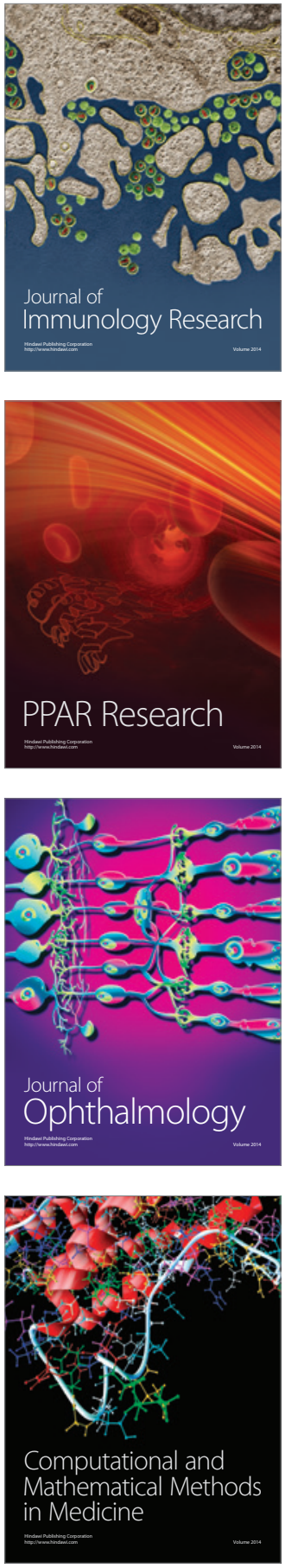

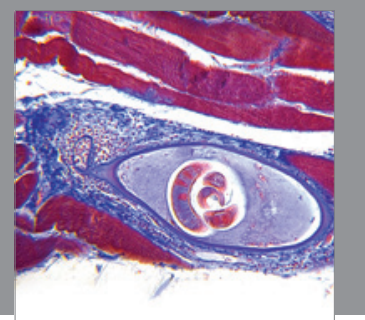

Gastroenterology

Research and Practice
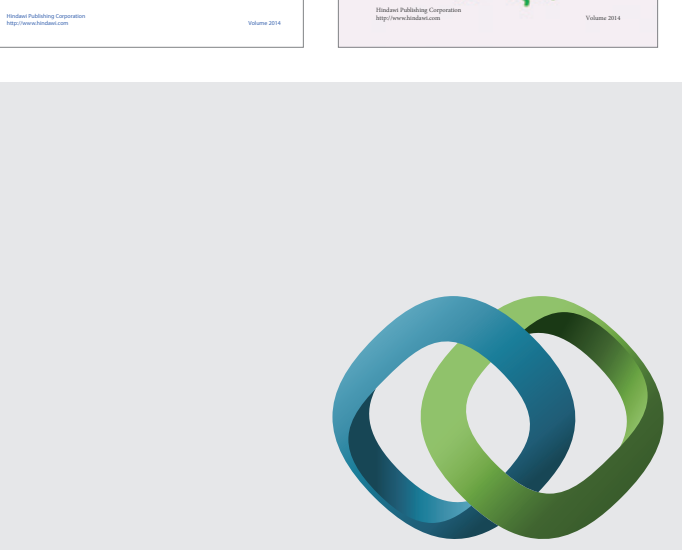

\section{Hindawi}

Submit your manuscripts at

http://www.hindawi.com
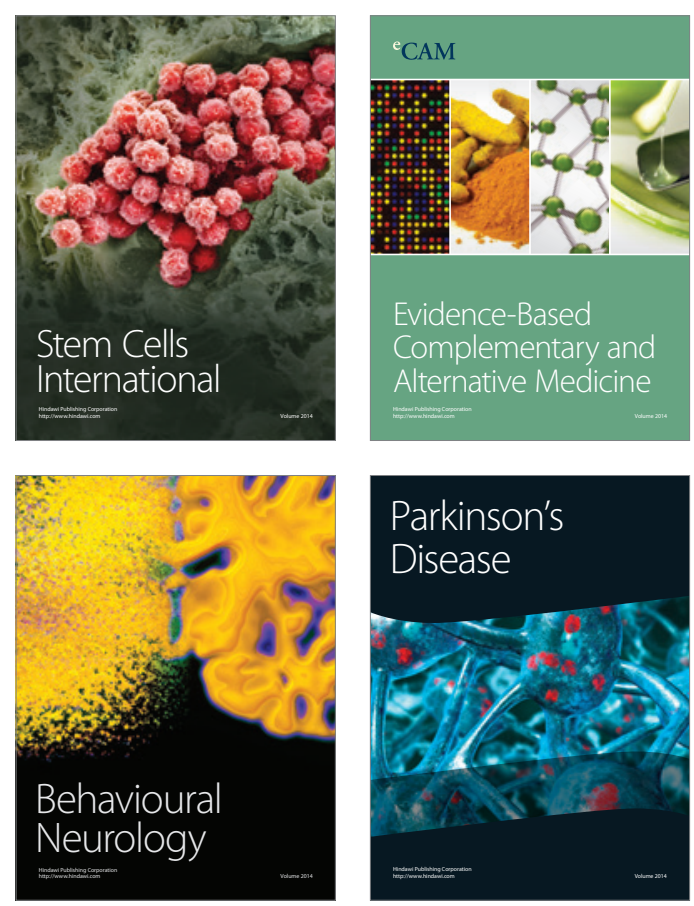

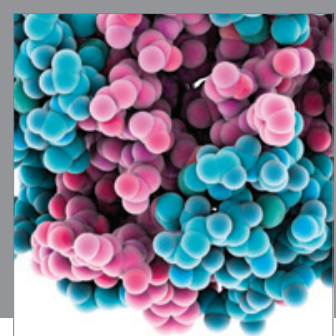

Journal of
Diabetes Research

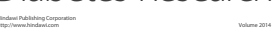

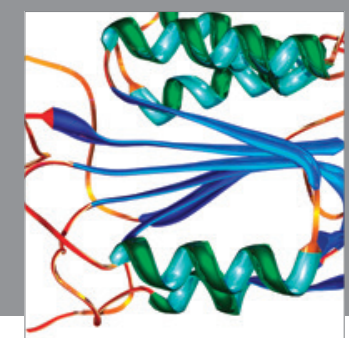

Disease Markers
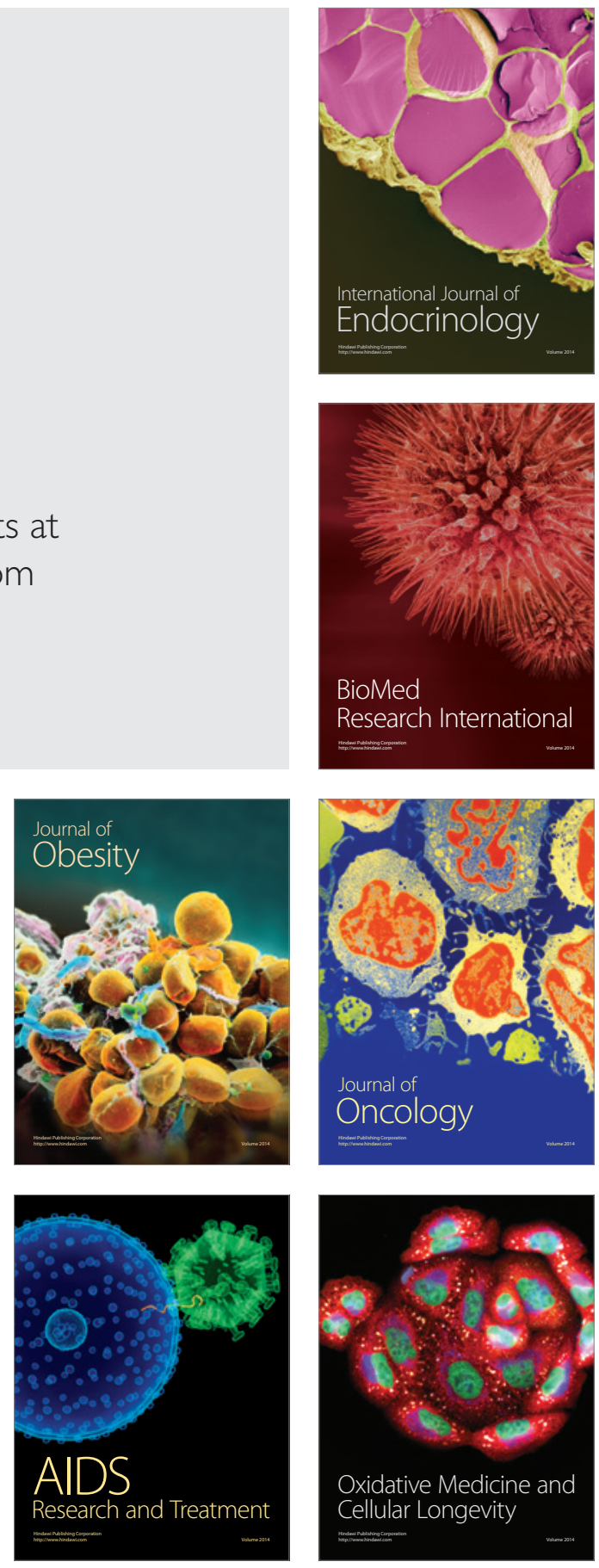